\title{
The Wages policy after Enactment of Government Regulation Number 78 year 2015 on Wages In Indonesia
}

\author{
Lalu Hadi Adha \\ Law Faculty of Mataram University \\ St. Majapahit No. 62 Mataram 83125, Telp. (0370), 633035. \\ E-mail:laluadhi@mail.com
}

\begin{abstract}
The emerge of pros and cons as always on the issue of minimum wages was a fact that indicates that wage issues are still a controversy and never done. The other hand, it can also be an indicator of the increasing awareness of workers to claim their rights. However, in case more examined closely the emerge of them are from the unaccommodated policies that are made. The determination policy of minimum wage has only understood an attempt to adjust to macroeconomic changes, but has never been seen in the context of real income development for workers.

The exposure has been written in this research, in effect to provide the alternative solutions for the realization of the accommodative wage policy. In this context, the government was required to neutral stand and accommodative functioning. In the end, the wage policy formulation analysis described and the analysis in this, to expected and create more comprehensive. Thus, the relationship between economic actors in industrial workers, employers and governments can work synergistically for better economic order.
\end{abstract}

Keywords: Wage, Policy, Enactment

\section{INTRODUCTION}

The recently that shows are still many Indonesian workers in low-income and lack of protection are issues in this country found. Therefore, in order not to be victim of opportunistic, the entrepreneur has push the government to considered the enactment of policy of the wage implementation. The wage determination is based on market mechanisms, it is certain that workers will earn very low, because of the abundance of labor in Indonesia. Thus, the policy of wage determination is intended to ensure employee income, increase productivity and develop the company in more efficient ways.

On the other hand seen the context of the wage minimum public policy by the government is acceptable. This relates to the reality that public policy generally derives from awareness of problems and the emergence of different interest groups in the struggle for resources and interests. In this context, wage policies are required in order to minimize the exploitation from employers of labor, and this regulation can be understood as the role of 
government in redistributing income.

The reasons and purpose of the establishment of the company are of establishing a government. The main purpose that can achieved by company through policy and appropriate reward system to ensure that was able to attract, retain and motivate high quality employees. With having and applying the right policies and good corporatesystems reputation as employers will be lifted and high quality human resources will be enticed to apply for the work. ${ }^{1}$

The policy in this may be interpreted by wages according to the employer or the applicable system in paying wages to workers in the company. In providing wages based on UMK (The District Minimum Wage) in areas where the company is located or in accordance with the government regulation. In managing the employer or company in giving wages to the workers, the government issued several regulations is The act No. 13 of 2003 on employment in article 88 paragraph (3) which regulates minimum wage, so that the employer can be based on the minimum wage set by the government. Government Regulation No. 8 of 1981 on Protection of Wages then changing with the Government Regulation No. 78 of 2015 on Remuneration still raises public dissatisfaction especially for labor and worker informal sector.

Positive correlation between the wages with increased productivity, in line with the concept of efficiency wage theory. In view of this theory, the determination of wage labor allows for increasing the nutrient can increase productivity. A wage increase also allows workers to send their children to school. Both in the long term will have a great impact on improvement the productivity. Thus, the existence of wages is expected to stimulate the growth of work and better.

Wage policies issued by the government always be controversy. For example. Once the UMK problem is over, it will definitely raise new problems. The emerge of the problem of wage system such as Provincial Minimum Wage in recent years, in fact is the implication of the unclear policies and regulations set by the government and regulatory changes that always occur if the government regime change. Therefore, it is interest to raised as a legal issue and the problem formulation in this research "How is the Wage policy protection in Indonesia after the enactment of Government Regulation No. 78 of 2015 on Wages?".

\section{METHOD}

\footnotetext{
${ }^{1}$ Achmad S. Ruky. (2001). Manajemen Penggajian \& Pengupahan Untuk Karyawan Perusahaan.Jakarta: PT Gramedia
} Pustaka Utama. p.1 
The research conducted by normative juridical, with legislation approach, analysis approach and conceptual approach.The legal material in this research are primary secondary and tertiary.

\section{ANALYSIS AND DISCUSSION}

\section{Theoretical Framework}

According to Prof. Benham : wages may be define as an amount of money paid by a person who provide an accupation for a worker for his services in accordance with its agreement. $^{2}$

Wages in islam are determined through negotiation between worker and employer based on the equality and equity principles, in purpose to guarantee decent wages for what has been given to the production. The basic principle on set the wages and wages amount according to syariah is an agreement between two parties by fair and decent consideration. As for the fair instruction on the payroll can be cite from surah an nahl:90 : " indeed, Allah orders justice and good conduct and giving to relatives and forbids immorality and bad conduct and oppression. He admonishes you that perhaps you will be reminded."3

By virtue of act number 13 of 2013 concerning worker stated that wages is a worker/labor rights which accepted and stated on the form of money as the reward from the entrepreneur or employer to the worker/labor which paid and determined according to the working agreement, deal or law regulation including the allowance for worker/labor and his family for their work or services that they have did or will be done. ${ }^{4}$ The provision of this wages oriented for the worker/labor welfare as the fulfillment of needs and/or necessity which is physically and spiritually, whether in or outside the working relation, which directly or indirectly able to increase the working productivity in the save and health work environment.

Theoretically, there are two system wages which based on the marxis and neoclassic theory. marx theory is based on the value theory that everybody have to workaccording to their ability and everyone get their wages based on their necessity. While neoclassic theory build the argument on the added value marginal production factor principle. On this matter,

\footnotetext{
2Afzalur, Rahman. (1995), Doktrin Ekonomi Islam Jilid II, Yogyakarta: PT. Dana Bhakti Waka, p. 361 ${ }^{3}$ Depag R.I, (2007), Al-qur'an Dan Terjemahannya, Surakarta: Media Insani Publishing, p. 227 ${ }^{4}$ BAB. 1 ,KetentuanUmum, Pasal 1 angka 30 Undang-Undang No 13 tahun 2013.
} 
Volume 1, Issue 2, October 2017

wages role as a reward for working effort which given from the worker for the entrepreneur. ${ }^{5}$ The two theories are thinking foundation in a state wages sytem. A wages sytem is not as pure as above framework, because it is adapted with the culture and characteristic of each country.

Particularly, the provision of wages in Indonesia is performed by the government. The provision formulation of wages for this time tend to only notice one or two indicators such as consumer price index and the comparative result with the minimum wages around its region. While other variables such as the company capability, company typology, company productivity, inflation rate and regional economic growth are often ignored. When the UMP is arise more than the inflation rate then many companies are out pf business because unable to bear the operational burden. In the future, the UMP increase more than inflation rate actually cannot be generalized on all industry sectors. Inheren in it, is need to divide the wages conception between the labor intensive industry sector and capital intensive industry sector. The increase on UMP for the capital intensive industry sector may be not as a big deal, however for the labor intensive industry sector (such as garment industry, electronic, whose etc), the increase on UMP is very burdensome. Other than that, it may be understood that the wages basicly is pay for performance so the wages increase should be based on the working productivity. On this matter, there is a contraception on the work of laborers. ${ }^{6}$

The wages system is a framework on how the wages is arranged and defined. Generally wages system in Indonesia is formed by based on the wages basic function which is to guarantee decent life for the workers and his family, also pictured the honorarium for someone working result and to provide the insentive to encourage an improvement on working productivity. ${ }^{7}$

Basic characteristic on wage system which listed on the working contract between worker and company consists of two things, which are the determination of unity wage output (piece rates) and time per hour wages (time rates). The selection of this wages type will affect many aspects, there are worker productivity and company benefit rates. The selection on wages is often arise a conflict between the entrepreneur and worker which derived from the entrepreneur ignorance concerning the working burden which performed by

\footnotetext{
${ }^{5}$ Simanjuntak, Payaman. (1985),Pengantar Ekonomi Sumber Daya Manusia ,Jakarta: Fakultas Ekonorni Universitas Indonesia.

${ }^{6}$ Suparjan dan Hempri Suyatno, Kebijakan Upah Minimum yang Akomodatif jurnail ilmu Sosial \& llmu Politik, Vol. 5, No 3, Maret 2002

${ }^{7}$ Suryahadi, A., Widyanti, W. P., Sumarto, S. (2003). Minimum Wage Policy and Its Implication on Employment in the Urban Formal Sektor. Bulletin of Indonesian Economic Studies. 39 (1). p. 29-50.
} 
the worker, while on the other perpectives the worker wish to have a high salary even on a very workload as small as possible.

The implementation on minimum wages policy in Indonesia was started since the establishment on indicator of minimum physical needs (KFM) in 1956 through the tripartite consensus and included the nutrisionists to advice a reference calculation on minimum wages. $^{8}$

Zainal Asikin on his book "Dasar-Dasar Hukum Perburuhan" expressed several theories concerning wages, namely :

a) The Normal Wages Theory, by David Ricardo

This theory statement, wage is determine by oriented on costs which required to pay all the worker life necessity. This theory assert to the worker, that some amount of money that they gain as a wages is naturally worth, because that is the only employer ability.

b) Theory of iron wage legislation, by Lassale

According to this theory, the normal wage above is only win the employer, because if this theory is guided, it will be easy for the employer to stated that it is the only amount that they able to give without consider how hard for the worker to from his job. Therefore, this theory argue that the worker should put an effort to against the normal wage theory for him to get life welfare.

c) Fund Wage Theory, by Stuart Mill Senior.

According to this theory, labor does not need against his employer as suggested on iron wages legislation theory, because the salary that he gets is according to the large amount of funds which available in the community, if the amount of the fund is big then the wage will be follow up for the labor, otherwise if the fund is reduces then the labor will accept less wages as well. This theory argued that the problem is not on how much the wages accepted, but on how far the wages will be able to fulfill all of the labor and his family necessity. Because this theory suggested, particularly to support the labor needs the government or employer have to provide particular fund which is called children fund. ${ }^{9}$

\section{The Role of the State in the Wage Policy}

The state are present in the form to reducing the burden of living expenses through

\footnotetext{
${ }^{8}$ Saget C. (2006). Fixing Minimum Wage Levels in Developing Countries: Common Failures and Remedies. ILO Geneve. Labor Studies Journal vol 1 (9). p. 11-24.

${ }^{9}$ Zainal Asikin. (2002), Dasar-dasar Hukum Perburuhan, Jakarta: PT Raja grafindo Persada, p. 68
} 
Volume 1, Issue 2, October 2017

social policies, such as education, social insurance via health insurance (BPJS) and employment insurance, labor housing, mass transportation, and community business credit (KUR) and layoffs victims can access. This policy ensures the state protection of the basic needs of workers and the community. With this, workers living expenses can suppressed. It is emphasized that the welfare of the workers is not dependent on the amount of wages received, but also the social facilities of the state that help reduce their expenses. The State present in the form of guidance and supervision on the bipartite social dialogue between employers and workers. Bipartite social dialogue is a key to workers welfare, including those related to the application of wage structures and scales, where wages are paid taking into consideration the working years, education, competence, and achievement or productivity.

In this context, workers are responsible for improving institutional and individual capacity in negotiating and the employer is responsible for opening the dialogue in order to make the bipartite forum work intensively and optimally. According with the wages formula, the minimum wage determination process begins from a Decent Living Needs Survey (KHL), then discussed in the wage council to be determined to be KHL. The value of KHL in the wage council scale to establish the amount of minimum wage.

The recent trend, the discussion of the minimum wage has always caused a polemic, due to absence the reference of standard in determining the minimum wage, to interpretation of article 88 paragraph (4) that minimum wage is determined by KHL and attention to productivity and economic growth.

\section{The Wages Policy}

The emerge of controversy when the wage minimum policy implies the existence of a problem in it. In this context, need to know that wisdom issues uncertain explicit, but must sought, and identified with correctly. Attempts to understand the true of the problem will helpful in determining the policy formulation process. The UMP policy should formulated by considere into aspects as justice, the availability of facilities and supporting infrastructure to the success and sustainability of the policies. Affirms that the justice principle in the wage should include several things, such as conformity with the needs of life, the resulting productivity, employment status, the contribution of workers to the organization, respect for the organization, compensation for equal work with other organizations. Always intertwined in the pros and cons of any wage increase policy, actually derives from the non-transparency of setting wage policies made. The dominant role of the government in determining salary and the absence of the same perception in the wage concept is the determinant factor causing the 
non-transparency of wage determination. By examining the existing empirical reality, the exposures below will offer four important matters with minimum wage standards.

1. The Indicators of Minimum wage determination

2. UMP implementation support

3. Structural reform and law enforcement

4. Transparency and communication of labor and employers

This policy is very urgent in minimizing the controversy of minimum wage fixing. In the future also need formulated a strategy for improving labor welfare. As one of the most vulnerable groups to fluctuations of the basic needs price, it's necessary public policy that allows the labor to solve the problem by looking at their expenses. The Labors in big cities generally spend their money on rent and transportation costs. Therefore, the construction of rental houses around the industrial estate able to save the expenses of them. This policy will encourage job creation and useful in assisting the structuring the city. While, for themselves, near the workplace is expected to increase their work productivity. The increase in labor productivity will run parallel with their wage and welfare.

\section{The Formulation of Wage Policy According to Government Regulation No. 78 of 2015}

As reported by various news that the Government has issued a new breakthrough regarding wages through Government Regulation (PP) No. 78 of 2015 on Wages. The most interesting thing in this PP is the formula of minimum wage increase which makes the minimum wage increase every year to be standard where the percentage of minimum wage increase are inflation plus economic growth. The minimum wage calculation formula brings new changes to the minimum wage setting process that has been in force recently.

While, sectoral minimum wage is determined as the result of negotiations between employer associations with the labor unions of sector concerned. The question how does the Group Minimum Business Wage (UMKU) also occur in some areas? the term of UMKU is not known in this Government Regulation or the previous regulations, so it needs to be adjusted.

Like the previous regulation, this PP still stressed that the minimum wage only applies to Labor with a working period less than 1 year. For labor whose working period more than 1 year then negotiated Bipartite with labor union within company.

\section{The provisions on minimum wage in Government Regulation No. 78 of 2015}

Government Regulation No. 78 of 2015 on Wages is an elaboration of Article 97 of the 
Act No. 13 of 2013 on Manpower, which regulated in this PP is use of national inflation rate variables and national economic growth as the main variable in the calculation of minimum wage increases. Besides, PP also regulates some detail on the issue of minimum wage. Stated in article 41 paragraph 2, according to this decree, the governor set a minimum wage as a safety net. The minimum wage referred to is the lowest monthly wage consisting of a. Unpaid wages or b. Basic wage including fixed allowances.

This government regulation confirms, that the minimum wage referred applies only to workers with tenure of less than 1 (one) year in the company concerned. Wages for workers for 1 (one) year or more are negotiated bipartite between the workers and the employer in the Company concerned. According to this PP, the determination of the minimum wage every year based on the needs of decent living and with due regard to productivity and economic growth. The needs for living as intended, according to this PP, is the standard requirement of a single worker/labor to fit physically able live for the needs of 1 (one) month, consisting of several components of the type of necessities of life. The intended components and types of living necessities as reviewed within 5 (five) years, Article 43 paragraph (5) of Government Regulation Number 78 of 2015.

In a review of the decent living requirement, the governor shall determine the provincial minimum wage (UMP) by taking into account the recommendation of the provincial wage council. The recommendation of the provincial wage council as referred to is based on the results of a review of the decent living needs which components are stipulated by the Minister and considere the productivity and economic growth, Article 45 paragraph (4) PP No. 78 of 2015. This regulation also states that the Governor may set wages minimum districts/city, that value should more than the provincial minimum wage.

\section{Sectoral minimum wage}

This Government Regulation also stipulates that the Governor may set the sectoral provincial and/or district/city minimum wages based on agreements between employers associations with labor unions in the sector concerned. Determination of sectoral minimum wage as according to this shall made after obtaining advice and consideration on the feature sector from provincial wage councils or district wage councils in accordance with their duties and authorities. In addition, the sectoral minimum wage must also be greater than the minimum wage of the district/city.

\section{Wags and non-wage income}

Wage policy is purposeto achieve income of wage and non-wage income that fulfill 
the livelihood of workers/labor. Wages are the right of workers/labor received in the form of money as reward from employers stipulated in employment agreements, company rules or collective labor agreements in accordance with the provisions of laws and regulations, including allowance for workers and their families. The wages consist of several components ; (i) unpaid wages; (ii) basic wages and fixed allowances or (iii) basic wages, fixed allowances and non-permanent allowance. Non-wage income may be religious holiday allowances, bonuses, work facility surrogates, and/or service payments in particular businesses.

Wages are set by time unit on a daily, weekly, or monthly, or unit of outcome in accordance of agreed occupation. The Employer are required to pay wages at the time was agreed by providing proof of payment of wages in rupiah currency of the Republic of Indonesia containing details of wages received by workers/labor. For matters of days or dates that fall on a holiday, weekly rest day, the payment of wages shall be governed by employment agreements, company rules or collective labor agreements. The periodic review of wages was made by employers to adjust for the price of living necessities and/or increases in work productivity by taking consider to the capabilities of the enterprise that are regulated in employment agreements, company regulations, or collective labor agreements.

\section{Type of wages}

Workers who are not come to work or do not work for reasons of absence and other activities than their work shall be paid their wages in employment agreementsstipulated, company rules or collective labor agreements. Employer who employ workers/labor beyond their working time or at weekly breaks or on official holidays, shall pay overtime as compensation to workers. Employer who will to provide severance pay to workers/labor, the basic components of calculating severance pay include;

1. Basic wages;

2. Fixed allowances that giving to workers and their families, including the purchase price of a free supply, which, when a worker shall be paid by subsidized labor, shall be considered as the difference between the purchase price and the price to be paid by workers/labor.

\section{Payments of wages in bankrupt circumstances}

The employer that was declared bankrupt by the court,and the wages rights of workers/labor are debt that be priority after payment to the creditors of the mortgage. If the 
Volume 1, Issue 2, October 2017

labor falls into bankruptcy then the wages and any payments arising from the employment are not included in the bankruptcy unless otherwise determine by the judge provided that no more than $25 \%$. If the money that provided by the employer to pay the wages is confiscatedby the bailiff under the court order then the confiscationshall not exceed $20 \%$ of the total wages.

\section{Minimum wage}

The local government (Governor) shall set the minimum wage for the lowest monthly wage of workers/laborers are consisting of wages without allowance or basic wages including fixed allowances. Determination the wages made every year based on the needs of decent living and due regard of productivity and economic growth. The Governor shall set the provincial and/or district/city sectoral minimum wages based on the agreement of the employers' association with the labor unions.

\section{Fines and wage deductions}

Employers or laborers who breaking the provisions of the employment agreement, company rules or collective labor agreements because of intent or negligence shall to fines if strictly regulated in employment agreements, company rules or collective labor agreements. Employers who late paying and/or not paying the agreed wages are subject to fines by following the terms is not omitting the obligation of employers to keep paying wages to the workers.

Wage deductions by the employers are for; (i) fines; (Ii) compensation; and/or (iii) the wage down payment in accordance with the employment agreement, company rules, or collective labor agreements. The total amount of wage deduction maximum $50 \%$ of wage received payment by the worker.

\section{Decent living needs according to government regulation number 78 years 2015}

Given the standard formula for the wage increases minimum, Government Regulation No. 78 of 2015 also tries to present the concept of total income received by workers. This means that income received by workers is not only the minimum wage but also all things received by the workers either the form as money or not. In Article 4 it is said that: Decent income is provided in the form as wages and non-wages. Wages consist of: Basic wages, fixed allowances, non-fixed allowances, related with the explanation of article 88 in The act No.13 of 2003, Decent living is the amount of income or income of the worker from they work as able to fulfill the life needs that includes food and beverages, clothing, housing, education, health, recreation, and pension insurance. So the increase/ the amount minimum wage does not absolutely determine the decent income to the workers. In this government 
regulation tries to convey a feasible concept by including something else from the outside of the minimum wage that workers receive as a pleasure.

\section{CONCLUSION}

Observe from the public policy context that minimum wage setting by the government is acceptable. This reality that public policyderives generally from awareness of problems and emergethe different interest groups in the struggle for resources and interests. In this, wage policy is necessary to minimize the exploitation of employers against labor, thus, the regulation in Government Regulation No. 78 of 2015 on Wages that we understood as the role of government for income distribution.

Addressing the controversy and problems always appearance when determination of the minimum wage policy needed was not just a temporary wage increase, but as a reform of the wage system. This system should reposition the workers and workers' lives as the axis of the ground and the base of motion. Furthermore, it should understood that the wage is not longer determined by the economic benefits, but also politically as a result of collective bargaining between workers' representatives and representatives of employers in lines granted by the State.The wage policy should formulated by considere into aspects such as justice, supporting infrastructure development for sustainability of the policy and affirming that the principle of welfare justice should include several things, as conformity with living necessities, productivity, employment status, workers' contribution to the organization, sense of responsibility towards the organization, comparison of wages for equal employment with other.

\section{Bibliography}

Abdul Rachmad Budiono, (2009),Hukum Perburuhan, PT. Indeks, Jakarta.

Abdul Rachmad Budiono, (2008),Hukum Pekerja Anak, Universitas Negeri Malang(UM PRESS), Malang.

Agusmidah, (2010), Hukum Ketenagakerjaan Indonesia Dinamika dan KajianTeori, Ghalia Indonesia, Bogor.

Asri Wijayanti, (2009),Hukum Ketenagakerjaan Pasca Reformasi, Sinar Grafika,Jakarta. 
Achmad S. Ruky. (2001). Manajemen Penggajian \& Pengupahan Untuk Karyawan Perusahaan.

Achmad Ali. (2012). Menguak Teori Hukum (Legal Theory) dan Teori Peradilan (Judicialprudence) Termasuk Interpretasi Undang-Undang (Legisprudence). Jakarta: Kencana.

Baqir Sharief Qorashi, tanpa tahun, Keringat Buruh, Hak dan Peran Pekerja Dalam Islam, Suparjan dan Hempri Suyatno,KebijakanUpahMinimum yang Akomodatif jurnailimu Sosial \&llmu Politik, Vol. 5, No 3, Maret 2002.

Suryahadi, A., Widyanti, W. P., Sumarto, S. (2003). Minimum Wage Policy and Its Implication on Employment in the Urban Formal Sektor. Bulletin of Indonesian Economic Studies. 39 (1).

Saget C. (2006). Fixing Minimum Wage Levels in Developing Countries: Common Failures and Remedies. ILO Geneve. Labor Studies Journal vol 1 (9). P. 11-24Jakarta: PT Gramedia Pustaka Utama.

Simanjuntak, Payaman. (1985). Pengantar Ekonomi Sumber Daya Manusia, Jakarta. Fakultas Ekonorni Universitas Indonesia.

Zainal Asikin. (2002). Dasar-dasar Hukum Perburuhan. Jakarta: PT Rajagrafindo Persada. 